Vol. 12 (2003): 213-225.

\title{
Variation in biomass related variables of reed canary grass
}

\author{
Mia Sahramaa, Helena Ihamäki \\ MTT Agrifood Research Finland, Plant Production Research, FIN-31600 Jokioinen, Finland, \\ e-mail:mia.sahramaa@mtt.fi \\ Lauri Jauhiainen \\ MTT Agrifood Research Finland, Research Services, FIN-31600 Jokioinen, Finland
}

\begin{abstract}
Reed canary grass, Phalaris arundinacea L., is a relatively new biomass crop in northern Europe, which produces raw material for bioenergy and paper pulp. Breeding reed canary grass for industrial purposes is under way in the absence of domestic cultivars being available. Knowledge of the extent of variation in biomass related traits is a basic requirement of the breeding programme. The aim of this study was to describe variation in biomass related traits and evaluate the relationships among the variables. Field experiment was carried out between 1994 and 1998 in Finland. Research material included wild and elite populations, which were divided into ten groups according to their origin. Biomass yield, plant fractions, shoot number, node number, leaf area and overwintering ability were measured. Panicle number, plant height and seed ripening were included to the analyses of the relationships. Results indicated the high biomass yield potential of reed canary grass, reaching over $13 \mathrm{t} \mathrm{DM} \mathrm{ha}^{-1}$ in the fourth year after establishment. Elite material and a local group from southern Finland had the highest biomass yield, whereas the northernmost local group had the lowest. Three factors established accounted for $45 \%$ of the variance and they were defined as "high biomass yield", "leaf-shoot relationship" and "fast development". The first factor indicated positive connections among biomass yield, panicle number, plant height, straw fraction and node fraction. This study indicated variation in agronomic traits of reed canary grass, which enables breeding of new cultivars with desired trait combinations.
\end{abstract}

Key words: Phalaris arundinacea L., industrial crop, factor analyses, plant fractions, variation, wild populations

\section{Introduction}

Reed canary grass (Phalaris arundinacea L., hereafter RCG) is a perennial, rhizomatous grass that is native to Finland, forms high, dense stands and produces substantial biomass. It is commonly grown for forage, particularly in North America, and more recently, for bioenergy in the Nordic countries. Furthermore, it can be used in paper pulp production, where it was demonstrated to be the most suitable crop of 17 herbaceous 


\section{AGRICULTURAL AND FOOD SCIENCE IN FINLAND}

\section{Sahramaa, M. et al. Variation in biomass related variables of reed canary grass}

species in Finland (Saijonkari-Pahkala 2001). In 2003 the cultivated area of RCG was reported to be 2700 hectares in Finland and 430 hectares in Sweden (Information Centre of the Finnish Ministry of Agriculture and Forestry 2003, Swedish Board of Agriculture 2003). Currently 75000 hectares of RCG are suggested to be cultivated for combustion until year 2010 in Finland (Leinonen et al. 2003). The recommended cultivation method is delayed harvest, meaning harvest in early spring (Landström et al. 1996). In Finnish studies, the amount of spring harvested biomass yield was about $2 \mathrm{t}$ dry matter (DM) ha-1 higher compared to autumn harvest in a long run, and there was no need for biomass drying (Pahkala and Pihala 2000). The quality of biomass also improved during a cold winter; fuel properties of spring harvested RCG are better than at autumn harvest because of a lower biomass mineral content (Flyktman 2000). However, the recommended amount of spring harvested RCG in the fuel mixture is still quite low (about 10\%), when there is usually no need for modifications to the fuel handling at the heating plant (Flyktman 2000). If autumn harvested RCG is used in fuel mixtures, its proportion should be very low to avoid combustion related problems.

Although spring harvest of RCG is best for non-food purposes, one or several harvests during the growing season might represent an alternative, e.g. in combined seed and biomass production. Seed yield is recommended to be harvested 15 days after anthesis in Finland (Sahramaa and Hömmö 2000a), and subsequent stand regrowth could be used for animal feed or for non-food purposes during autumn or the following spring. The regrowth ability of RCG was about $20 \%$ in a two cut system in Finland, when first harvest was performed at flowering stage and second in October (Saijonkari-Pahkala 2001). In biomass production two or three cuts during the growing season may produce average or improved DM yield over a single harvest depending on the year, although spring harvest has provided the highest biomass yield in the long term (Pahkala 1997, Saijonkari-Pahkala 2001).
Previous studies had showed that late cutting in autumn may have a negative effect on subsequent seed yield (Hillestad 1994, Jonassen 1994). Seed productivity could possibly be extended by harvesting seed every second year (Myllylä and Myllylä 2000). Repeated autumn harvest also affected the biomass yield by decreasing the quality, although both autumn (August) and spring (May) yields remained relatively constant over the eight years of the study (SaijonkariPahkala 2001). Subsequent autumn cutting resulted in more weeds in the stand and decreased stem number when compared with spring harvest (Pahkala and Mela 2000).

As RCG is a new species for bioenergy in Northern Europe, more information is needed of its potential as a biomass plant. Biomass yield had shown to have the greatest effect on economy of the production (Klemola et al. 2000). This study aimed at describing variation in biomass yield, plant proportions, shoot number, node number, leaf area and overwintering ability of local Finnish wild populations and elite material. In addition to establishing the extent of variation in improved cultivars, promising new sources of variation for breeding were sought from wild germplasm. An additional aim was to illustrate the relationships among traits related to biomass yield. Panicle number, plant height and seed ripening were included to the analyses of the relationships from previous studies (Sahramaa et al. 2004, Sahramaa and Jauhiainen 2003). One objective was to find out which factors have the greatest effect on biomass yield. The results of this study will furnish new information of the potential of RCG as a biomass plant and serve as a basis for further investigations and practical breeding.

\section{Material and methods}

Field experiment with 53 wild RCG populations, eight cultivars and 14 breeding lines (Fig. 1, Table 1) was carried out at MTT Agrifood Research 


\section{AGRICULTURAL AND FOOD SCIENCE IN FINLAND}

Vol. 12 (2003): 213-225.

in Jokioinen, Finland $\left(60^{\circ} 49^{\prime} \mathrm{N}\right)$ in the years 1994-1998. The experiment was a randomized complete block design with four replicates. Each plot $\left(1.25 \mathrm{~m}^{2}\right)$ consisted of 30 individual plants. The distance between plots was $2.5 \mathrm{~m}$. Nitrogen fertilizer at $40-70 \mathrm{~kg} \mathrm{~N}^{-1}$ was given after spring harvest. No herbicides were used. The detailed field management is described by Sahramaa and Jauhiainen (2003). Aerial biomass was harvested to stubble height of 10-12 cm in May before the onset of the new growing season. In 1995 harvest was done manually, and in 19961998 using a harvester (Haldrop 8 R, Danmark).

Total fresh matter yield was recorded. A plant sample (hundred litres) taken from each plot was crushed to 3-4 $\mathrm{cm}$ sections using a chaff cutter (Walter u. Wintersteiger KG, Austria). Two random samples of crushed and mixed RCG (50$100 \mathrm{~g}$ ) were weighed and dried in an oven (Heraeus UT 5100, Memmert UL60) at $105^{\circ} \mathrm{C}$ for two hours, after which temperature was adjusted to $60^{\circ} \mathrm{C}$ for $12-15$ hours. Dry matter content and dry matter yield were determined subsequently.

Proportions of plant fractions (\%) were measured from 25 stems harvested in spring 1996. Stems were cut at ground level and dried in a warm-air dryer at $+30^{\circ} \mathrm{C}$ (Koja Ltd., Finland) for three days. Single stems were divided into four parts: 1) straw, 2) leaves and leaf sheaths, 3) nodes and 4) shoots. Panicle and stem to the uppermost node (about $10 \mathrm{~cm}$ ) were removed. After division, samples were dried again at $60^{\circ} \mathrm{C}$ for 12-14 hours and weight of the various components was measured. In addition to plant fractions, numbers of nodal shoots per stem were assessed from the same material.

In 1995 and 1996 node number was counted from five randomly chosen stems in each plot. Number of nodes per stem was measured three times in 1995 before complete anthesis and five times in 1996 before seed ripening. Leaf area index (LAI) of the canopy was measured using a LICOR-2000 canopy analyzer (LI-COR, USA) at eight points within the plot area. The sensor was placed near the soil surface. In 1995, measurements were done eight times at about weekly

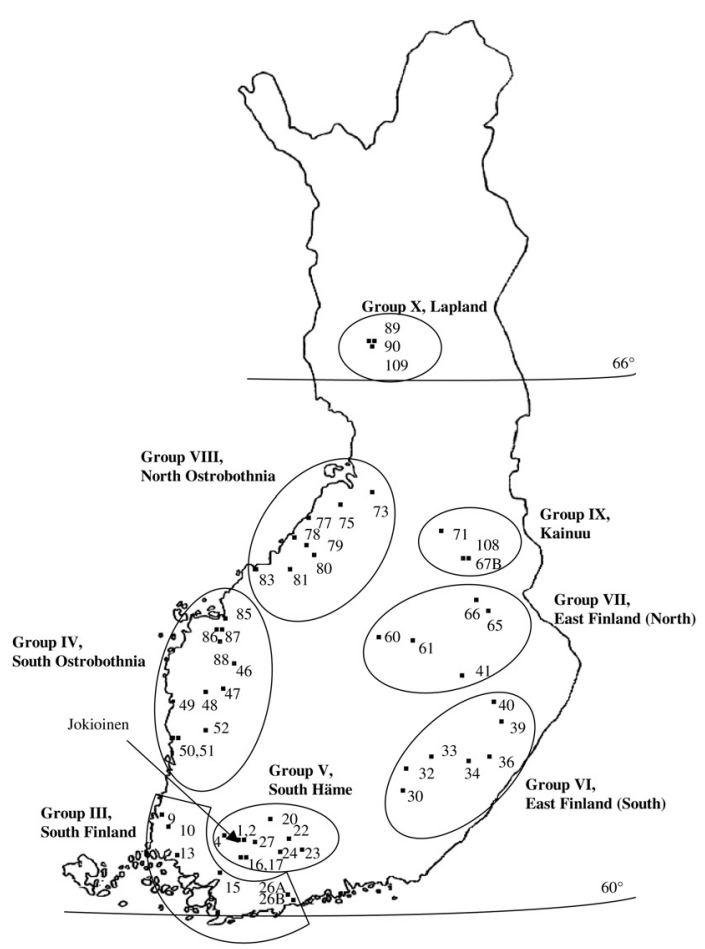

Fig. 1. Geographic origins of the wild populations (53) of reed canary grass included in an experiment conducted at Jokioinen, Finland in 1994-1998 (Source: Sahramaa and Jauhiainen 2003).

intervals starting in May before emergence of flag leaf until complete anthesis. The final measurement was taken after seed ripening in the end of August. In 1996, LAI was measured four times starting before emergence of flag leaf in May until anthesis in July. Overwintering ability (\%) was determined visually for each plot in each year after spring harvest when growing was started. In 1995 and 1996 single plants (30 per plot) were distinguishable and overwintering percentage was measured by counting the overwintered plants per plot. Subsequently plants grew together and overwintering percentage was measured as a proportion of the plot area. Plant sampling and analyses of panicle number, plant height and seed ripening were described earlier by Sahramaa and Jauhiainen (2003) and Sahramaa et al. (2004). 


\section{AGRICULTURAL AND FOOD SCIENCE IN FINLAND}

\section{Sahramaa, M. et al. Variation in biomass related variables of reed canary grass}

Table 1. Origins of cultivars and breeding lines of reed canary grass included in an experiment conducted at Jokioinen, Finland in 1994-1998.

\begin{tabular}{|c|c|c|}
\hline I Cultivars (8) & Country & Maintainer \\
\hline Palaton & USA & Peterson Seed Co., Minnesota \\
\hline Pervenets & Russia & \\
\hline Barphal & Netherlands & Barenbrug \\
\hline Vantage & USA & Iowa Agricultural Experiment Station \\
\hline Venture & USA, seed bulked in Finland & Peterson Seed Co., Minnesota \\
\hline Rival & Canada & University of Manitoba \\
\hline Motterwitzer & Germany & DSG-Berlin \\
\hline Venture & USA & Peterson Seed Co., Minnesota \\
\hline II Breeding lines (14) & Country & Region \\
\hline SWA5 & Norway & \\
\hline SWB17 & Denmark & \\
\hline SWD33 & Austria & \\
\hline SWG63 & Russia & \\
\hline SWJ91 & Canada & \\
\hline SW91065 & Sweden & Uppland \\
\hline SW91066 & Sweden & Uppland \\
\hline SW91067 & Sweden & Uppland \\
\hline SW1 & Sweden & Risudden \\
\hline SW2 & Sweden & Blattnicksele \\
\hline SW3 & Poland & \\
\hline SW4 & Switzerland & \\
\hline SW5 & Russia & \\
\hline Jo0510 & Finland & \\
\hline
\end{tabular}

Material was divided into ten groups of which cultivars were the first (I) and breeding lines the second (II) (Table 1). Wild populations were divided into an additional eight groups according to their geographic origin: III) South Finland, IV) South Ostrobothnia, V) South Häme, VI) East Finland (South), VII) East Finland (North) VIII) North Ostrobothnia, IX) Kainuu and X) Lapland (Fig. 1). Grouping was based on biogeographical provinces of Finland (Hämet-Ahti et al. 1998), which were slightly enlarged to form groups of reasonable size.

\section{Statistical methods}

DM yield and overwintering ability were measured each year for plants in each plot. Node number and LAI were measured several times a year. The repeated measurements were correlat- ed and the correlation was taken into account in the statistical models. The covariance structure for the repeated measurements was chosen after comparing all biologically sensible structures using Akaike's information criterion (Wolfinger 1996). Therefore, the response variable (Y) was analysed according to the statistical model (Gumpertz and Brownie 1993):

$\mathrm{Y}_{\mathrm{ijk}}=\mu+$ block $_{\mathrm{k}}+$ treatment $_{\mathrm{i}}+{\text { treatment } \times \text { block }_{\mathrm{ik}}}$

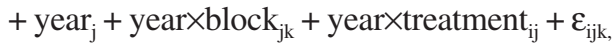

where $\mu$ is the constant and treatment ${ }_{i}$, year $_{j}$ and treatment $\times$ year $_{\mathrm{ij}}$ represent the fixed effect associated with the $i^{\text {th }}$ treatment, $\mathrm{j}^{\text {th }}$ year and their interaction, respectively. The effect of treatment includes both the effect of group and the effect of population. Block $\mathrm{k}_{\mathrm{k}}$, treatment $\times$ block $_{\mathrm{ik}}$, year $\times$ block $_{\mathrm{jk}}$ and $\varepsilon_{\mathrm{ijk}}$ represent the normally distributed random effect of block, between plots error, between years error and within plots error, re- 
Vol. 12 (2003): 213-225.

Table 2. Biomass yield ( $\mathrm{kg} \mathrm{DM} \mathrm{ha}^{-1}$ ) of reed canary grass cultivars (I), breeding lines (II) and wild populations (III to X) at spring harvest in an experiment conducted at Jokioinen, Finland in 1995-1998.

\begin{tabular}{|c|c|c|c|c|c|}
\hline Group & $1995^{1)}$ & 1996 & 1997 & 1998 & $\begin{array}{l}\text { Means of the years } \\
1996-1998\end{array}$ \\
\hline I & $2783^{a}$ & $10133^{a}$ & $12922^{\mathrm{a}}$ & $15937^{\mathrm{a}}$ & $12779^{a}$ \\
\hline II & $1026^{\mathrm{e}}$ & $8816^{\text {bc }}$ & $11718^{\mathrm{b}}$ & $16117^{a}$ & $11852^{\mathrm{b}}$ \\
\hline III & $1487^{b}$ & $8504^{\text {bcd }}$ & $11658^{\mathrm{b}}$ & $14274^{\mathrm{b}}$ & $11227^{\mathrm{bc}}$ \\
\hline IV & $1383^{\mathrm{bc}}$ & $8981^{\mathrm{b}}$ & $10982^{\mathrm{bc}}$ & $13495^{\mathrm{bc}}$ & $11000^{\mathrm{cd}}$ \\
\hline V & $1321^{\text {bcd }}$ & $8225^{\text {cde }}$ & $10419^{\mathrm{cd}}$ & $14267^{\mathrm{b}}$ & $10693^{\text {cde }}$ \\
\hline VI & $1179^{\text {cde }}$ & $7528^{\mathrm{e}}$ & $10486^{\mathrm{cd}}$ & $13289^{\mathrm{bc}}$ & $10161^{\text {ef }}$ \\
\hline VII & $1019^{\mathrm{e}}$ & $7782^{\mathrm{de}}$ & $10314^{\mathrm{cd}}$ & $13679^{\mathrm{bc}}$ & $10317^{\mathrm{def}}$ \\
\hline VIII & $1125^{\mathrm{de}}$ & $7589^{\mathrm{e}}$ & $9982^{\mathrm{d}}$ & $12437^{\mathrm{c}}$ & $9803^{f}$ \\
\hline IX & $1070^{\mathrm{de}}$ & $8675^{\text {bce }}$ & $8772^{\mathrm{e}}$ & $12123^{c}$ & $9735^{f}$ \\
\hline$X$ & $263^{f}$ & $4446^{f}$ & $5412^{\mathrm{f}}$ & $8569^{d}$ & $5908^{\mathrm{g}}$ \\
\hline mean & 1114 & 7913 & 10035 & 13242 & 10169 \\
\hline
\end{tabular}

Between group comparisons: estimated means with the same letter are not significantly different $(\mathrm{P}>0.05)$.

1) Year 1995 was analysed separately (ANOVA for randomized complete block design).

spectively. All random effects are mutually independent and the $\varepsilon_{\mathrm{ijk}}$ 's of one plot are correlated as early defined. In 1995 LAI was analysed using daily temperature sum as the repeated measurement factor instead of year. The effective temperature sum $\left({ }^{\circ} \mathrm{C} \mathrm{dd}\right.$, days of degree) was calculated from the beginning of the growing season. According to the Finnish Meteorological Institute, the thermal growing season was considered to have begun once the daily temperature exceeded $+5^{\circ} \mathrm{C}$. Second degree polynomials were used to model effects of treatment and temperature sum. Proportion of fractions and shoot number per stem were analysed using the traditional ANOVA for a randomised complete block design. Data were transformed with arcsine-square root or natural logarithm prior to analysis.

Assumptions of models for normality and constancy of error variance were checked using graphical methods; scatter diagrams for constancy of error variance and box plots for normality of errors. The assumptions were achieved after log-transformation in analysis of DM yield. All presented estimates were transformed to the original scale. The parameters of the models were estimated using the REML estimation method in PROC MIXED in SAS system for Windows, release 8.2 (Littell et al. 1996).
Not all selected variables for RCG were necessarily related to the biomass. Factor analysis was used to establish which variables were related to high biomass, how strong the relation was and how the variables were correlated. Correlations between variables were measured using residuals, because original observations from the same block and from the same population were dependent. Only residuals from 1995 were used. Factor analysis with varimax rotation was used to determine the relationships among all variables and to divide variables into a few groups. A Pearson correlation coefficient was used to determine linear associations between two variables and to confirm the associations found from the factor analysis. Correlation and factor analyses were performed using the PROC CORR and PROC FACTOR (Hatcher 1994) respectively.

\section{Results}

The average yield increased from $7.9 \mathrm{t} \mathrm{DM} \mathrm{ha}^{-1}$ to13.2 t DM ha ${ }^{-1}$ between 1996 and 1998 (Table 2). In that time the overall mean for yield was $10.2 \mathrm{t} \mathrm{DM} \mathrm{ha}^{-1}$. In the first harvest year 


\section{Sahramaa, M. et al. Variation in biomass related variables of reed canary grass}

Table 3. Proportion of plant fractions (\%) and number of shoots per stem of reed canary grass cultivars (I), breeding lines (II) and wild populations (III to X) in an experiment conducted at Jokioinen, Finland in spring 1996.

\begin{tabular}{|c|c|c|c|c|c|c|c|c|c|c|c|}
\hline Fraction (\%) of DM & I & II & III & $\begin{array}{l}\text { Group } \\
\text { IV }\end{array}$ & V & VI & VII & VIII & IX & $\mathrm{X}$ & Mean \\
\hline Straw & $58^{\mathrm{bc}}$ & $56^{\mathrm{c}}$ & $59^{\mathrm{abc}}$ & $61^{\mathrm{a}}$ & $59^{\mathrm{ab}}$ & $60^{\mathrm{ab}}$ & $59^{\mathrm{ab}}$ & $61^{\mathrm{a}}$ & $61^{\mathrm{ab}}$ & $55^{\mathrm{c}}$ & 59 \\
\hline Leaf and leaf sheath & $17^{\mathrm{f}}$ & $18^{\mathrm{f}}$ & $22^{\mathrm{e}}$ & $23^{\mathrm{d}}$ & $24^{\mathrm{cd}}$ & $21^{\mathrm{e}}$ & $24^{\text {bcd }}$ & $26^{\mathrm{b}}$ & $25^{\mathrm{bc}}$ & $29^{\mathrm{a}}$ & 23 \\
\hline Node & $7^{\mathrm{ef}}$ & $6^{\mathrm{g}}$ & $6^{\mathrm{fg}}$ & $7^{\mathrm{cd}}$ & $7^{\mathrm{de}}$ & $7^{\mathrm{bc}}$ & $7^{\mathrm{bcd}}$ & $7^{\mathrm{cd}}$ & $8^{\mathrm{a}}$ & $8^{\mathrm{ab}}$ & 7 \\
\hline Shoot & $16^{\mathrm{a}}$ & $15^{\mathrm{a}}$ & $8^{\mathrm{b}}$ & $3^{\mathrm{c}}$ & $5^{\mathrm{f}}$ & $8^{\mathrm{b}}$ & $3^{\mathrm{c}}$ & $1^{\mathrm{d}}$ & $1^{\mathrm{de}}$ & $0.4^{\mathrm{e}}$ & 5 \\
\hline Shoot number & $2.2^{\mathrm{b}}$ & $2.0^{\mathrm{a}}$ & $1.3^{\mathrm{c}}$ & $0.8^{\mathrm{d}}$ & $1.2^{\mathrm{c}}$ & $1.2^{\mathrm{c}}$ & $0.8^{\mathrm{d}}$ & $0.4^{\mathrm{e}}$ & $0.3^{\mathrm{e}}$ & $0.2^{\mathrm{e}}$ & 1.1 \\
\hline
\end{tabular}

Between group comparisons: estimated means with the same letter are not significantly different $(\mathrm{P}>0.05)$.

(1995) the average DM yield was only about one t DM ha- ${ }^{-1}$. The difference in DM yield among the groups was significant in each year. Cultivars (I) produced significantly more than all other groups. Cultivars and breeding (II) lines had the highest yield, and breeding lines even slightly exceeded cultivars in the fourth harvest. Furthermore, breeding lines and the southernmost group (III) produced significantly higher yield than wild groups (VI, VII, VIII, IX and X). All groups differed significantly from the northernmost group (X), which produced the lowest yield.

The average proportion of fractions in a stem was 59\% straw, 23\% leaves and leaf sheaths, $7 \%$ nodes and $5 \%$ shoots (Table 3 ). The difference in plant fractions among the groups was significant. Straw fraction was highest among the wild groups IV, VIII and IX and lowest for breeding lines (II) and the northernmost group (X). Fraction of leaves and leaf sheaths was highest for the northernmost group (X) and lowest among cultivars and breeding lines. Node fraction ranged from 6 to $8 \%$ depending on group. Shoot fraction was highest for cultivars $(16 \%)$ and breeding lines (15\%) and only $0-8 \%$ for the wild populations, being lowest for the northernmost groups (VIII, IX, X). RCG had on average 1.1 shoots per stem originating from upper nodes, ranging from 0 to 6 . Cultivars and breeding lines had the highest shoot number, approximately two, and they also differed significantly from other groups. Local groups III, V and VI had approximately 1.2 nodal shoots per stem and they differed significantly from other local groups, which had only one or zero shoots.

RCG had approximately 5 to 6 nodes per stem at the beginning of anthesis (data not shown). Subsequently this trait was not studied. In 1995, plant development was fast and node number already 4.5 at the beginning of June during flag leaf emergence, whereas in 1996, at the same time, node number was only 1.1 and flag leaves had not emerged. In 1995, node number was 6.1, when the last measurement was made at the end of June at the beginning of anthesis. In 1996, the last measurement was taken at the end of July when anthesis was complete and node number was 5.6. Statistical analyses established significant differences in node number among groups of RCG, but they were not very meaningful.

The difference in overwintering ability among groups of RCG was significant. During four years the northernmost group (X) had the highest overwintering ability $(95 \%)$ and cultivars $(85 \%)$ the lowest, and they differed significantly from other groups. The average overwintering ability of RCG was high $(90 \%)$ over four years although it decreased each year being $97 \%$ in 1995 and $85 \%$ in 1998.

LAI as a function of accumulated temperature sums $\left({ }^{\circ} \mathrm{C} \mathrm{dd}\right)$ was estimated by quadratic polynomials for each RCG group in 1995 (Fig. 2). Quadratic polynomials appeared to fit the data both visually and statistically well $\left(\mathrm{R}^{2}=0.71\right)$. Groups differed significantly (Fig. 2) from each other in shape of profiles, which con- 


\section{AGRICULTURAL AND FOOD SCIENCE IN FINLAND}

Vol. 12 (2003): 213-225.

LAI
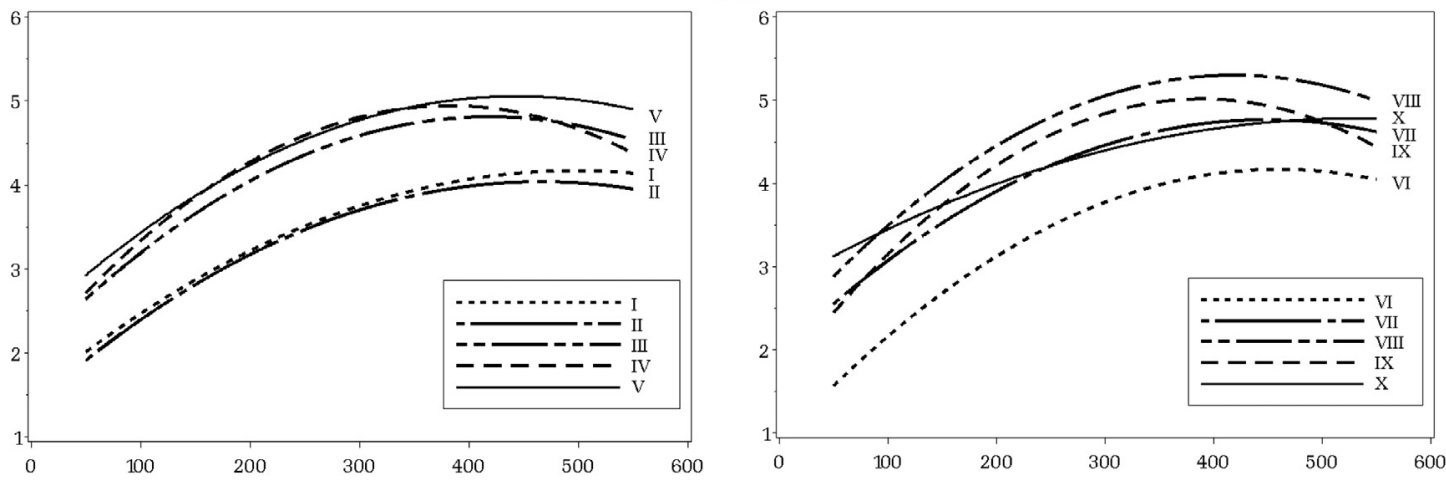

Temperature sum $\left({ }^{\circ} \mathrm{C}\right.$ dd $)$

Statistical significance

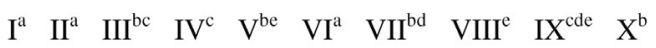

Fig. 2. Leaf area index (LAI) of reed canary grass cultivars (I), breeding lines (II) and wild populations (III to X) as accumulated temperature sum $\left({ }^{\circ} \mathrm{C} \mathrm{dd}\right)$ from the beginning of growing season in an experiment conducted at Jokioinen, Finland in 1995.

sisted of three parameters: constant, linear and quadratic term. Wild groups V, VIII and IX had the highest LAI values and cultivars, breeding lines and group VI the lowest. Wild group VIII had the highest value for LAI but it was reached after a relatively long time. LAI values for group IX decreased more rapidly after peaking than did those for group VIII. Cultivars, breeding lines and group VI had almost same LAI profiles, generally low values for LAI and late peak values. The northernmost group (X) had a similar profile to cultivars, breeding lines and group VI, but higher LAI values. The mean value for LAI was 1.8 at first measurement in May, and 4.7 at its highest during the beginning of anthesis at the end of June 1995. Subsequently LAI decreased to 3.6 at the end of August. The differences in LAI values were significant among the groups also in 1996 (Table 4). Again, the highest LAI values were recorded for groups V and VIII and the lowest for group VI and for cultivars. LAI was measured only four times and it was already 3.4 at first measurement at the end of May. The highest value (6.9) was recorded at the end of June at the time of inflorescence appearance. A
Table 4. Leaf area index of reed canary grass cultivars (I), breeding lines (II) and wild populations (III to X) in an experiment conducted at Jokioinen, Finland in 1996.

\begin{tabular}{|c|c|c|c|c|}
\hline Group & $\begin{array}{l}\text { First } \\
30 \text { May }\end{array}$ & $\begin{array}{l}\text { Second } \\
11 \text { Jun }\end{array}$ & $\begin{array}{l}\text { Third } \\
\text { 24 Jun }\end{array}$ & $\begin{array}{l}\text { Fourth } \\
8 \mathrm{Jul}\end{array}$ \\
\hline I & $2.7^{\mathrm{e}}$ & $5.0^{\mathrm{e}}$ & $6.0^{\mathrm{g}}$ & $5.5^{\mathrm{d}}$ \\
\hline II & $3.1^{\mathrm{cd}}$ & $5.2^{\mathrm{d}}$ & $6.3^{\mathrm{ef}}$ & $5.9^{c}$ \\
\hline III & $3.3^{\mathrm{bc}}$ & $6.1^{\mathrm{b}}$ & $7.3^{\mathrm{bc}}$ & $6.2^{\mathrm{bc}}$ \\
\hline IV & $3.4^{\mathrm{b}}$ & $6.2^{\mathrm{ab}}$ & $7.2^{\mathrm{c}}$ & $6.1^{\mathrm{c}}$ \\
\hline $\mathrm{V}$ & $3.9^{\mathrm{a}}$ & $6.3^{\mathrm{ab}}$ & $7.6^{\mathrm{a}}$ & $7.2^{\mathrm{a}}$ \\
\hline VI & $3.0^{\text {de }}$ & $5.1^{\mathrm{de}}$ & $6.2^{\mathrm{fg}}$ & $5.9^{c}$ \\
\hline VII & $3.4^{\mathrm{bc}}$ & $5.7^{\mathrm{c}}$ & $7.1^{\mathrm{cd}}$ & $6.5^{\mathrm{b}}$ \\
\hline VIII & $3.9^{\mathrm{a}}$ & $6.5^{\mathrm{a}}$ & $7.5^{\mathrm{ab}}$ & $7.0^{\mathrm{a}}$ \\
\hline IX & $3.4^{\mathrm{bc}}$ & $5.9^{\mathrm{bc}}$ & $7.0^{\mathrm{cd}}$ & $6.2^{\mathrm{bc}}$ \\
\hline$X$ & $4.0^{\mathrm{a}}$ & $6.1^{\mathrm{abc}}$ & $6.7^{\text {de }}$ & $5.9^{\mathrm{cd}}$ \\
\hline mean & 3.4 & 5.8 & 6.9 & 6.2 \\
\hline
\end{tabular}

Between group comparisons: estimated means with the same letter are not significantly different $(\mathrm{P}>0.05)$.

final record was taken at anthesis at the beginning of July, when LAI was slightly lower (6.2).

Factor analyses included 12 variables from which three factors were retained (Table 5) using the scree test (Cattell 1966). The factors were 


\section{Sahramaa, M. et al. Variation in biomass related variables of reed canary grass}

Table 5. Factor loadings for agronomic traits of reed canary grass in an experiment conducted at Jokioinen, Finland, in 1995. Factor loadings below 0.4 are omitted for clarity.

\begin{tabular}{llll}
\hline Specification & \multicolumn{3}{l}{ Factor } \\
\cline { 2 - 4 } & High biomass yield & Leaf-shoot relationship & Fast development \\
\hline Explains of total variance (\%) & 21.0 & 14.3 & 10.0 \\
Variable & & factor loading & \\
\hline Biomass yield (kg DM ha-1) & +0.49 & & \\
Panicle number (m ${ }^{-2}$ ) & +0.50 & & \\
Shoot number (per stem) & -0.58 & +0.45 & +0.43 \\
Node number (per stem) & & & \\
Plant height (cm) & +0.41 & -0.48 & -0.69 \\
Leaf area index (per surface) & -0.48 & & +0.54 \\
Seed ripening (days of degree) & & & \\
Overwintering (\%) & & & \\
Straw fraction (\%) & +0.59 & -0.76 & \\
Leaf and leaf sheath fraction (\%) & & +0.44 & \\
Shoot fraction (\%) & -0.74 & & \\
Node fraction (\%) & +0.54 & & \\
\hline
\end{tabular}

termed "high biomass yield", "leaf-shoot relationship" and "fast development" and they accounted $45 \%$ of the variance. The first factor (explaining $21 \%$ of the variation) indicated a positive relationship between biomass yield (loading $=+0.49)$, panicle number $(+0.50)$, plant height $(+0.41)$, straw fraction $(+0.59)$ and node fraction $(+0.54)$. Correlation coefficients also revealed these associations. The first factor was the most important as it explained most of the variance. The highest negative loading came from shoot fraction $(-0.74)$ and other negative loadings from shoot number and leaf area. These variables indicated their negative relationship to high biomass yield. The second factor (14\% explanation) revealed the negative relationship between leaves and shoots of RCG. The second factor was established without effects from biomass or development variables, as they constituted the first and third factors. Positive loadings came from shoot number $(+0.45)$ and shoot fraction $(+0.44)$, whereas negative loadings came from leaf fraction $(-0.76)$ and leaf area index $(-0.48)$. The third factor (10\% explanation) in- dicated a connection between good overwintering and high node number, whereas a negative loading came from seed ripening.

Several positive and negative correlations were evident (Table 6). Biomass yield was positively correlated with panicle number, plant height, straw fraction and node fraction. Correspondingly, biomass yield was negatively correlated with LAI and shoot fraction. Furthermore, panicle number was positively correlated with plant height, node number, straw fraction and node fraction. Panicle number was negatively correlated with shoot number, shoot fraction, LAI and leaf fraction. The highest positive correlation was found between shoot number and shoot fraction (0.64). LAI and leaf fraction were also positively correlated $(0.23)$ as well as LAI and shoot fraction (0.17). Highest negative correlations were found between straw fraction and shoot fraction $(-0.40)$, between shoot fraction and leaf fraction $(-0.33)$ and between biomass yield and LAI (-0.31). No significant differences were established in correlations between advanced and wild material. 
Vol. 12 (2003): 213-225.

Table 6. Statistically significant $(\mathrm{P}<0.05)$ Pearson correlation coefficients $(\mathrm{n}=300)$ among agronomic traits of reed canary grass in an experiment conducted at Jokioinen, Finland, in 1995.

\begin{tabular}{|c|c|c|c|c|c|c|c|c|c|c|c|}
\hline & $\begin{array}{l}\text { Panicle } \\
\text { number }\end{array}$ & $\begin{array}{l}\text { Shoot } \\
\text { number }\end{array}$ & $\begin{array}{l}\text { Node } \\
\text { number }\end{array}$ & $\begin{array}{l}\text { Plant } \\
\text { height }\end{array}$ & $\begin{array}{l}\text { Leaf area } \\
\text { index }\end{array}$ & $\begin{array}{l}\text { Seed } \\
\text { ripening }\end{array}$ & $\begin{array}{l}\text { Over- } \\
\text { wintering }\end{array}$ & $\begin{array}{l}\text { Straw } \\
\text { fraction }\end{array}$ & $\begin{array}{l}\text { Leaf } \\
\text { fraction }\end{array}$ & $\begin{array}{l}\text { Shoot } \\
\text { fraction }\end{array}$ & $\begin{array}{l}\text { Node } \\
\text { fraction }\end{array}$ \\
\hline Biomass yield & 0.27 & -0.10 & & 0.19 & -0.31 & & 0.10 & 0.12 & & -0.21 & 0.14 \\
\hline Node fraction & 0.18 & -0.16 & & 0.17 & -0.22 & 0.10 & & 0.36 & & -0.18 & \\
\hline Shoot fraction & -0.18 & 0.64 & & -0.16 & 0.17 & & & -0.40 & -0.33 & & \\
\hline Leaf fraction & -0.17 & -0.22 & & -0.12 & 0.23 & & & 0.19 & & & \\
\hline Straw fraction & 0.17 & -0.17 & & & -0.14 & & 0.11 & & & & \\
\hline Overwintering & & & 0.10 & & & & & & & & \\
\hline Seed ripening & -0.11 & & & & -0.12 & & & & & & \\
\hline Leaf area index & -0.21 & & -0.13 & -0.21 & & & & & & & \\
\hline Plant height & 0.26 & & & & & & & & & & \\
\hline Node number & 0.13 & & & & & & & & & & \\
\hline Shoot number & -0.14 & & & & & & & & & & \\
\hline
\end{tabular}

Nearly significant $(\mathrm{P}<0.10)$ correlation coefficients are indicated in cursive.

LAI at seed ripening stage was used for correlation and factor analyses. However, correlation between LAI and biomass yield was determined for each time of measurement in order to determine its possible influence on correlation. In 1995 the correlation changed from positive to negative during eight measurements (Table 7). During early stages of development, i.e. during flag leaf and inflorescence emergence, the correlation between LAI and biomass yield was positive. At anthesis the correlation changed from positive to negative and consequently, was negative at seed ripening stage.

\section{Discussion}

This study indicated the high yield potential of RCG. The mean biomass yield of RCG was $10 \mathrm{t}$ $\mathrm{DM} \mathrm{ha}^{-1}$ during the three years over which the trial was conducted. According to previous studies (Saijonkari-Pahkala 2001), RCG was the most promising species for biomass production in Finland together with tall fescue (Festuca arundinacea Schreb.), yielding typically 7-8 t $\mathrm{DM} \mathrm{ha}^{-1}$. In this study, factor analysis provided a useful approach to determine which of 12 var-

Table 7. Leaf area index (LAI) and correlation between LAI and biomass yield of reed canary grass over eight parameters measured in an experiment conducted at Jokioinen, Finland in 1995.

\begin{tabular}{llcc}
\hline Date & Stage of development & LAI & LAI $\times$ Biomass yield \\
\hline 23 May & Before flag leaf emergence & 1.8 & 0.04 \\
31 May & Before flag leaf emergence & 3.6 & 0.09 \\
9 Jun & Flag leaf emerged & 3.9 & 0.33 \\
15 Jun & Inflorescence emerged & 4.6 & 0.27 \\
21 Jun & Beginning of anthesis & 4.7 & 0.15 \\
28 Jun & Anthesis & 4.7 & -0.03 \\
6 Jul & Completed anthesis & 4.4 & -0.04 \\
28 Aug & Afted seed ripened & 3.6 & -0.31 \\
\hline
\end{tabular}




\section{AGRICULTURAL AND FOOD SCIENCE IN FINLAND}

\section{Sahramaa, M. et al. Variation in biomass related variables of reed canary grass}

iables were related to high biomass yield and how strong the relationship was. Altogether three factors were established, of which the factor of "high biomass yield" was the most important one. Results showed that biomass yield was generally high when there were plenty of panicles in a tall stemmed plant stand. This study emphasised that high biomass yield of RCG might be connected with high straw fraction, which has shown to be profitable in non-food production. One explanation for that might be the delayed cultivation method in non-food production, where plant stand can develop during the whole growing season without cutting until the final harvest in spring and therefore, stands become more stemmed. Leaves also shatter naturally during winter and harvest and consequently, straw proportion is higher in spring harvest than in autumn harvest (Pahkala and Mela 2000). Straw fraction provides highest pulp yield with improved quality, and low quality leaf blades and sheaths have been removed by fractionation before cooking (Saijonkari-Pahkala 2001). A higher proportion of stems results in better quality and higher energy production. In a previous study, straw fraction had the lowest mineral content when populations selected for further breeding were analysed (Sahramaa and Hömmö 2000b).

RCG plant stand density increased in this study; the values of LAI were clearly higher in the second year than in the first year after establishment. In general, LAI values of RCG fluctuated as for other forage grasses (from 2 to 6) (Holmes 1989). In Finnish studies, LAI values for Phleum pratense L. and Festuca pratensis Huds. were similar to those of RCG at inflorescence emergence (Virkajärvi and Järvenranta 2001, Virkajärvi et al. 2002). However, as RCG is cultivated for industrial purposes, the plant stand is not harvested during the growing season. Therefore, measurements of LAI were done also during later stages of development. In this study, factor and correlation analysis were performed using LAI measured at seed ripening stage, because at that time RCG had completed most of its growth and therefore, populations were more comparable. That developmental stage also described better the cultivation practise for a non-food crop. However, during early stages of development, high leaf area indicated early growth vigour and thereby, high biomass yield. Interpretation of LAI changed with an aged plant stand i.e. at seed ripening stage, when high leaf area indicated low biomass yield. A possible explanation for this change from positive to negative correlation was the growth pattern; RCG has the most enhanced growth (stem elongation) around flag leaf and inflorescence emergence, and negligible growth after seed ripening (Sahramaa and Jauhiainen 2003). Although biomass yield still increases after seed ripening it is probably more due to shooting and nodal branching than increased leaf area. A dense RCG stand also decreases the leaf growth, because lower leaves are shaded.

The factor associated with the "leaf-shoot relationship" indicated that increase of one will decrease the other. That for "fast development" suggested that good overwintering results enhanced early plant development. RCG node number increased rapidly during the growing season indicating stem lengthening. Results from earlier study showed that RCG reached $98 \%$ of the maximum plant height at seed ripening (Sahramaa and Jauhiainen 2003). However, node number and plant height were not correlated in this study, and one reason for that might have been failure to take measurements after anthesis. There are also other traits, not studied here, which are possibly important in formation of biomass yield of RCG. These include number of tillers per plant, individual mass of each tiller and seed number.

This study showed that there were marked differences among groups of RCG in DM yield, plant fractions, shoot number, node number, leaf area and overwintering ability. Variation recorded for biomass yield among groups of different genotypes indicates possibilities to improve the economics of cultivation through plant breeding directed towards increased biomass. Most of the populations studied were local wild populations examined for the first time under field conditions 
Vol. 12 (2003): 213-225.

but many were high yielding. Cultivars and breeding lines differed from other groups through having the highest biomass yield, highest shoot number and shoot proportion and low straw fraction. According to previous study (Sahramaa et al. 2004) they had also the highest panicle number. This reflects the impact of breeding for forage, where plant stand is usually cut several times during the growing season and where the regrowth capacity is the most important trait. Cultivars and breeding lines bred for forage were also assumed to be the leafiest, but surprisingly, that was not the case. Cultivars and breeding lines had lower LAI values and proportion of leaf fraction than wild populations.

Local groups also differed from each other in those agronomic traits studied. Local populations from coastal areas in southern Finland (III, IV) had the highest biomass yield, which was close to that of elite material. Local populations generally had the highest straw fraction, but a weak capacity to produce shoots. They also had the highest proportion of leaf fraction and high LAI values. In summary, when high straw yield is a breeding objective, local populations with high straw content from South and North Ostrobothnia (IV, VIII) and from Kainuu (IX) should be used. These could be crossed with cultivars and breeding lines showing the highest biomass yield potential. Another reason for using local populations in breeding might be their better adaptation to local conditions than foreign cultivars. There was indication of better overwintering ability of wild populations although overwintering capacity was generally quite high. Of all the material studied, the northernmost wild group (X) exhibited the poorest agronomic traits from the non-food production point of view: lowest biomass yield and straw fraction, and highest leaf fraction. However, the northernmost group had the best overwintering ability, being approximately $10 \%$ higher than that of cultivars. As all populations were evaluated only in southern Finland, information of the genotype by environment interaction was not achieved. However, it was not possible to increase the experimental places, because lack of collected seed and high population number. The results from this study indicate the possibilities for breeding more suitable cultivars than current forage cultivars for nonfood production. Furthermore, most of the populations evaluated here are stored in the Nordic Gene Bank and are available for use in the future.

\section{Conclusions}

According to the results of this study, groups of RCG representing different geographical origin differed significantly from each other in biomass related traits. RCG had high biomass yield during three years. Cultivars and breeding lines reflected the impact of forage breeding by having the highest biomass yield and shoot number, whereas local populations usually had the highest straw fraction. However, local groups from coastal areas in southern Finland had high biomass yield, even close to that of elite material, and those sites could be potential collection areas for local germplasm. Factor analyses included 12 variables of which three factors "high biomass yield", "leaf-shoot relationship" and "fast development" were retained. According to those results panicle number, plant height, straw fraction and node fraction were related to high biomass. Good overwintering was found to be connected to fast and early plant development. High biomass yield in combination with high straw fraction would be optimal in non-food production. Considerable variation found in agronomic traits in this study indicated that breeding of new RCG cultivars for food or non food purposes might be possible by crossing foreign elite material with local germplasm.

Acknowledgements. This study was funded by the Academy of Finland, MTT Agrifood Research Finland and the Finnish Ministry of Agriculture and Forestry. The authors are grateful to Dr Leena Hömmö at Ministry of Agriculture and Forestry for her implementation of the experiments, and to the technical staff at MTT Plant Production Research for their valuable contribution. Prof Pirjo Peltonen-Sainio is warmly thanked for her comments on the manuscript. 


\title{
AGRICULTURAL AND FOOD SCIENCE IN FINLAND
}

\author{
Sahramaa, M. et al. Variation in biomass related variables of reed canary grass
}

\section{References}

Cattell, R.B. 1966. The scree test for the number of factors. Multivariate Behavioral Research 1: 245-276.

Flyktman, M. 2000. Ruokohelven seospoltto turpeen ja puun kanssa. Abstract: Reed canary grass in mixed combustion with peat and wood-based fuels. In: Salo, R. (ed.). Production of biomass as raw material for fibre and energy. II. Harvesting of reed canary grass and straw, production costs and combustion techniques. Publications of Agricultural Research Centre of Finland. Serie A 85. p. 140-169. (in Finnish).

Gumpertz, M. \& Brownie, C. 1993. Repeated measures in randomized block and split-plot experiments. Canadian Journal of Forest Research 23: 625-639.

Hämet-Ahti, L., Suominen, J., Ulvinen, T. \& Uotila, P. 1998. Retkeilykasvio. Luonnontieteellisen keskusmuseon kasvimuseo. Yliopistopaino, Helsinki. 656 p.

Hatcher, L. 1994. A step-by-step approach to using the SAS system for factor analysis and structural equation modelling. Cary, NC: SAS Institute Inc. 588 p.

Hillestad, R. 1994. Seed production of reed canarygrass (Phalaris arundinacea L.) in Norway. In: NJF-seminarium nr. 241. Fröproduktion. Jokioinen, Finland. p. 113-116.

Holmes, W. 1989. Grass, its production and utilization. Second edition. Published for the British Grassland Society by Blackwell Scientific Publications. 306 p.

Jonassen, G.H. 1994. Autumn treatment in reed canarygrass (Phalaris arundinacea L.) and smooth bromegrass (Bromus inermis L.) for seed production. In: NJF-seminarium nr. 241. Fröproduktion. Jokioinen, Finland. p. 123-133.

Klemola, E., Laine, A., Maunu, T. \& Palonen, J. 2000. Ruokohelven ja oljen tuotantokustannus, saatavuus ja korjuuvarmuus. Abstract: Production costs, availability and harvesting reliability of reed canary grass and straw. In: Salo, R. (ed.). Production of biomass as raw material for fibre and energy. II. Harvesting of reed canary grass and straw, production costs and combustion techniques. Publications of Agricultural Research Centre of Finland. Serie A 85. p. 112139.

Landström, S., Lomakka, L. \& Andersson, S. 1996. Harvest in spring improves yield and quality of reed canary grass as a bioenergy crop. Biomass and Bioenergy 11: 333-341.

Leinonen, A., Paappanen, T., Flyktman, M., Erkkilä, A., Pahkala, K. \& Sahramaa, M. 2003. Peltoenergian tutkimus- ja kehityssuunnitelma vuosille 2003-2007. In: Esitys kansalliseksi peltoenergiaohjelmaksi 20032010, Finbio 25. 68 p. (in Finnish).
Littell, R.C., Milliken, G.A., Stroup, W.W. \& Wolfinger, R.D. 1996. SAS System for mixed models. SAS Institute, Inc., NC, USA. 633 p.

Myllylä, K. \& Myllylä, M. 2000. Peltosellutehtaan raakaainehuolto. Ruokohelpihankkeen loppuraportti EMOTR. Peltosellu Oy, Oulu. 76 p. (in Finnish).

Pahkala, K. 1997. Sellua peltokasveista. Peltokasvien soveltuvuus sellun raaka-aineeksi. Lisensiaatintutkimus. Kasvinviljelytiede, Kasvintuotantotieteen laitos, Helsingin yliopisto. Julkaisu 47. 117 p (in Finnish).

Pahkala, K. \& Mela, T. 2000. Ruokohelven viljelymenetelmät. Abstract: Cultivation methods for reed canary grass. In: Salo, R. (ed.). Production of biomass as raw material for fibre and energy. I. Breeding and cultivation of reed canary grass. Publications of Agricultural Research Centre of Finland. Serie A 84. p. 15-31. (in Finnish).

Pahkala, K. \& Pihala, M. 2000. Different plant parts as raw material for fuel and pulp production. Industrial Crops and Products 11: 119-128.

Sahramaa, M. \& Hömmö, L. 2000a. Seed production characters and germination performance of reed canary grass in Finland. Agricultural and Food Science in Finland 9: 239-251.

Sahramaa, M. \& Hömmö, L. 2000b. Ruokohelven jalostustutkimus. Abstract: Breeding research of reed canary grass. In: Salo, R. (ed.). Production of biomass as raw material for fibre and energy. I. Breeding and cultivation of reed canary grass. Publications of $\mathrm{Ag}$ ricultural Research Centre of Finland. Serie A 84. p. 7-14. (in Finnish).

Sahramaa, M., Hömmö, L. \& Jauhiainen, L. 2004. Variation in seed production traits of reed canary grass germplasm. Crop Science 44, 3: (in press).

Sahramaa, M. \& Jauhiainen, L. 2003. Characterization of development and stem elongation of reed canary grass under northern conditions. Industrial Crops and Products 18, 2: 155-169.

Saijonkari-Pahkala, K. 2001. Non-wood plants as raw material for pulp and paper. Agricultural and Food Science in Finland 10, supplement 1. 101 p.

Virkajärvi, P. \& Järvenranta, K. 2001. Leaf dynamics of timothy and meadow fescue under Nordic conditions. Grass and Forage Science 56: 294-304.

Virkajärvi, P., Sairanen, A., Nousiainen, J.I. \& Khalili, H. 2002. Effect of herbage allowance on pasture utilization, regrowth and milk yield of dairy cows in early, mid and late season. Animal Feed Science and Technology 97, 1-2: 23-40.

Wolfinger, R.D. 1996. Heterogeneous variance-covariance structures for repeated measures. Journal of Agricultural, Biological, and Environmental Statistics 2: 205-230. 


\title{
AGRICULTURAL AND FOOD SCIENCE IN FINLAND
}

Vol. 12 (2003): 213-225.

\section{SELOSTUS}

\section{Ruokohelven biomassan tuotantoon vaikuttavien ominaisuuksien vaihtelu}

\author{
Mia Sahramaa, Helena Ihamäki ja Lauri Jauhiainen \\ MTT (Maa- ja elintarviketalouden tutkimuskeskus)
}

\begin{abstract}
Monivuotinen ruokohelpi (Phalaris arundinacea L.) on melko uusi bioenergian ja paperin raaka-aineeksi soveltuva heinäkasvi Pohjois-Euroopassa. Ruokohelven lajikejalostus aloitettiin Suomessa, koska kotimaisia lajikkeita ei ole jalostettu. Agronomisesti tärkeiden ominaisuuksien riittävä geneettinen muuntelu on uusien lajikkeiden tuottamisen perusta. Tämän tutkimuksen tavoitteena oli selvittää biomassan tuotantoon liittyvien ominaisuuksien vaihtelua ja niiden välisiä riippuvuuksia.

Tutkimusaineisto kerättiin suomalaisesta kenttäkokeesta vuosina 1994-1998. Aineisto koostui villeistä ja jalostetuista ruokohelvistä, jotka jaettiin kymmeneen ryhmään alkuperän perusteella. Kokeesta määritettiin biomassasato, eri kasvinosien osuudet, korren solmuista lähtevien versojen lukumäärä, solmujen lukumäärä, lehtiala ja talvehtiminen. Riippuvuuksien tarkasteluun otettiin mukaan myös röyhyjen lukumäärä, kasvin pituus ja tuleentuminen.
\end{abstract}

Tulokset osoittivat, että ruokohelvellä on suuri satopotentiaali. Biomassasato oli neljäntenä korjuuvuonna yli $13 \mathrm{t} \mathrm{ka} \mathrm{ha-1}$. Jalostetulla aineistolla ja eteläsuomalaisella villeistä populaatioista koostuvalla ryhmällä oli suurin biomassasato, kun taas kaikkein pohjoisimmalla ryhmällä sato oli heikoin. Tutkimuksessa selvitettiin kaikkien ominaisuuksien välisiä yhteyksiä. Ominaisuuksista muodostettiin kolme erillistä kokonaisuutta, faktoria, jotka olivat "korkea biomassasato", "lehti-verso" sekä "nopean kehittymisen faktori". Muodostuneet faktorit selittivät $45 \%$ aineistossa esiintyvästä kokonaisvaihtelusta. Biomassasato suureni, kun röyhyjen lukumäärä neliömetrillä lisääntyi, kasvusto piteni, korren osuus kasvista suureni tai solmujen osuus korressa lisääntyi. Kaikkien mitattujen ominaisuuksien suhteen aineistossa esiintyi runsaasti vaihtelua, mikä mahdollistaa uusien lajikkeiden jalostamisen. 
